\title{
VALUE OF FOREST SHELTER-BELTS IN THE STEPPE OF UKRAINE
}

\author{
Vozhehova R. A., Hranovska L. M.
}

\section{INTRODUCTION}

Forest is the most powerful and effective ecosystem stabilizer especially in the Steppe zone. 300 years ago, forests covered $40 \%$ of the territory of Ukraine. At present, by the official data the cover is only $15.7 \%$, according to unofficial ones it is less than $10 \%{ }^{1}$. According to the calculations of ecologists, the level of forest cover in the Steppe zone of Ukraine should be at least $9 \%$, at present this index does not exceed $5.5 \%{ }^{2}$.

The positive effect of forests on agricultural landscapes has been known for a long time. Forest plantations are a powerful bioenergetic factor, serve as a reliable human's assistant in combating drought. Even at a young age, they significantly affect the regulation of runoff, the hydrological regime of locations, and the increase in crop yields. The main objects of agroforestry are the centers of ecological destabilization, where the degradation of agrarian landscapes is progressing.

Sudden changes in the ratio of the land fund of landscapes, especially forest plantations and agricultural land, have led to the transformation of the ecological situation and increased the effects of unfavorable natural and anthropogenic phenomena ${ }^{3}$. At the end of the nineteenth century V.V. Dokuchaiev proposed the idea of the optimization of territories by which in the regions of agriculture there should be a certain ratio between plowing, meadows and forest, and in the Steppe zone, in his view, the forest cover should be raised to $15-18 \%{ }^{4}$.

In the fields situated in the Steppe zone, the following effects of forest shelter-belts on agricultural landscapes could be traced: Windspeed decreases (total range of influence - 50-100 heights $(\mathrm{H})$; effective one $-25-30 \mathrm{H}$; windspeed decreases by $30-50 \%{ }^{5}$; Relative humidity of air under hot winds

\footnotetext{
1 Agro-ecological monitoring and certification of agricultural lands (methodological and regulatory support) / ed. V.P. Patyka. K.: Phytosociocenter, 2002. 295 p.

Gladun G.B., Trofimenko M.E., Lokhmatova M.A. Forest shelter-belts: design, cultivation, arrangement / Ed. G.B. Gladunov. Kh.: Nove slovo, 2005. 390 p.

${ }^{3}$ David O. Ekhuemelo. 2016. Importance of Forest and Trees in sustaining Water supply and Rainfall. https://www.researchgate.net/publication.

${ }_{4}$ Zaichenko Y.S., Maksimenko N.V. The ecological role of forest shelter-belts in Kharkiv region. Environmental protection and rational use of natural resources. Collection of reports VII Donetsk: DonNU, 2008. P. 237-238.

${ }^{5}$ Netherer S., Schopf A. (2010). Potential effects of climate change on insect herbivores in European forests - General aspects and the pine processionary moth as specific example. Forest Ecology and Management. 259: 831-838.
} 
increases by $2-5 \%$ and temperature drops by $2-3^{0} \mathrm{C}$; Evaporation from soil surface decreases by 20-25\%; Transpiration decreases, its productivity increases by $10 \%$; Snow is hold back on the fields; Snow-distributing properties of forest belts are improved by their constructions - dense, tracery, crafty; Productive moisture contents increase by $30-50 \mathrm{~mm}$; Soils and crops are protected at the occurrence of sandstorms; Soil properties and their fertility are improved under the prolonged activity of forest belts (25-30 years and more); Crop yield increases on the fields, which are protected by forest belts, (in the zone up to $25-30 \mathrm{H}$ ) by $10-20 \%$; grain crops - by $3-5 \mathrm{cwt} / \mathrm{ha}$.

The main features of the Steppe zone are the increasing aridity of the climate, the presence of halogen soils having a high tendency to erosion, which leads to significant yield losses. But it should be mentioned that the cause of bad harvest in the Steppe zone is not only a small amount of rainfall, but also a very low level of their absorption, which is $30-35 \%$ in summer and $40-80 \%$ in winter depending on the depth of soil freezing.

In the system of measures of the improvement of moisture accumulation in crops and control of droughts in the Steppe zone, forest shelter-belts play an extremely important role, it has been particularly evident in the recent years in connection with increasing aridity of the climate. They reduce wind strength, hold snow and water in the fields, prevent soil erosion and improve the microclimate in crops. Their positive effect on crop production is manifested in all years - both during droughts, sandstorms, and under favorable conditions of a vegetation period.

As early as 1892 , K.A. Timiryazev in his lectures pointed out that the main measure to combat droughts in the Steppe regions is planting hedges and forest shelter-belts. Because of droughts and manifestation of wind erosion, especially in the 1892, 1928, 1946 and 1947, starting from the end of the IX century, forest belts has begun to be planted in the Forest-steppe and Steppe zones, which were then continued immediately in the post-war years. In order to prevent droughts, sand and dust storms, in the late 1940s and early 1950s, a project was developed to create vast state forest shelter-belts with a length exceeding $5300 \mathrm{~km}$ and a width of $60-100 \mathrm{~m}$, as well as local ones that were planted around the perimeter of individual fields, on the slopes of gullies and on the sands, which was intended for the period of 1949-1965. The creation of forest shelter-belts continued until the early 1980s and was almost frozen during the reconstruction period since 1985 .

\section{Analysis of current state of the forest belts along the Kakhovka main canal}

Forest strips along irrigation canals are heavily thinned. Types of the forest shelter-belts along the main canal depend on their main functions: 
- runoff-regulating (water-regulating, snow-distributing) forest shelterbelts - holding and regulating surface runoff, favoring equal snow distribution on the adjacent watershed territories, decrease of soil washing away, improvement of microclimate;

- hollow forest plantations - holding solid runoff by the bottom and on the cone including: clog-filtering - to precipitate solid runoff directly in the canals of hydrographic network and prevent clogging of the canal, favoring to farm use of unsuitable low-productive lands. This type of afforestation should be located when constructing a canal in the cavity, within the most advanced hydrographic network of hollows and gullies to prevent and reduce the volume of runoff into the main Kakhovka canal;

- forest belts near the canal - a type of forest shelter-belts that is especially important for reducing the force of wind directly above the channel of the canal, protecting the canal from clogging, dust and vehicle emissions, shading the canal and improving the microclimate and hydrological regime of the canal area.

The influence of canal forest shelter-belts on the microclimate largely depends on the structure of the forest belt. The spread of pollutants, dust and litter that is carried by the airflows in the surface layer to the canal and the channel area is delayed better by a non-crafty forest shelter-belt up to 10 tree heights tall. In this case, the deposition of large-dusted fractions and litter occurs directly in the forest shelter-belt, and the presence of the effect of turbulence causes the sedimentation of the remaining pollution at distances exceeding 10 tree heights.

A crafty forest shelter-belt of a projected height planted at the highest markings of the upper berm of the canal creates a barrier to air flow and, due to turbulence, will cause pollution to settle outside the canal. This is an important aspect of forest shelter-belts performing an ecological function.

Open and crafty forest shelter-belts generally reduce air speed, resulting in the accumulation of contaminants directly on the distance of up to 10 tree heights.

Investigation of the current conditions of forest shelter-belts and analysis of the degree of damage to trees by pests and diseases were carried out by visual inspection to determine the extent of damage to trees. Examinations of existing trees were carried out, their condition and degree of pests and diseases were evaluated by three gradations: low degree of impact up to $25 \%$; average - up to 50\%; high - exceeding 50\%. Most forest pests belong to the insect class, to a lesser extent, some other species of mites and vertebrates are also harmful. Depending on the nature of the food, pests of the forest are divided into leaf-eating (primary), which damage healthy woody plants; stem (secondary) ones, damaging weakened trees; root or soil ones. 
Leaf-eating pests are particularly diverse and numerous; they include representatives of different species of leaf-fed insects. In larval and adult stages (imago), they lead an open lifestyle (only some of them in the larval stage live inside the leaves), so they are directly affected by climatic conditions. They are characterized by large fluctuations in numbers; they form colonies mainly in young plantations. Under favorable conditions, forest pests periodically produce outbreaks of massive reproduction. Each outbreak usually takes 7 generations and consists of 4 stages: the initial (the number of the pest increases slightly), the increase in the number (colonies of forest pests are formed), the actual outbreak (the pests of the forest appear in the mass and strongly harm the crowns of trees), crisis (the outbreak slows down $)^{6}$.

During the outbreak of massive reproduction, leaf-eating insects are relatively easy to spread over a large area over a short period of time and cause considerable damage to trees, causing loss of additional growth, weakening and further drying of trees or entire forest plantations.

In addition to sanitary and preventive measures, chemical ones are used against leaf-eating pests. The plantations are treated with insecticides, usually during the increase in their numbers, when the larvae are at a younger age, less resistant to them and when there is little damage to the good fauna. Biological measures of control include the use of resettlement of good birds (hanging nestling boxes for tits), creation of new plantations including shrubs, fruit tree species for their best attraction, use of parasitic fungi, bacteria, viruses and other pathogens of pests ${ }^{7}$.

Stem pests of forest are very numerous, belong to the group of beetles (mainly bark beetles, buprestidae, snout beetles), hymenoptera (horntails) and butterflies (sesiidae, etc.). As a rule, they live a hidden life, open lifestyle is a feature of only mature insects (bark beetles live most part of their life inside the tissues of cambium). Gnawing strokes in the bark, cambium and wood they often cause trees to wilt; many of them make deep traces in the trunks, devaluing the timber. Massive reproduction depends on the viability of trees, plantations and their sanitary condition. Stem pests inhabit usually weakened trees. In plantations with poor sanitary status or located near the centers of massive reproduction of secondary pests, often even quite healthy trees are inhabited by them ${ }^{8}$. Control measures are mainly preventive: forestry measures that increase the biological stability of plantations (creation of mixed crops with undergrowth, selection of breeds in accordance with

\footnotetext{
${ }^{6}$ Gusev V.I. Determinant of damage to forest, ornamental and fruit trees and shrubs. M.: Forest. Ind., 1984. $470 \mathrm{p}$.

${ }^{7}$ Tsylyuryk A.V., Shevchenko S.V. Forest phytopathology (Workbook). Korsun-Shevchenkovsky: Irena, 1999. $203 \mathrm{p}$.

${ }^{8}$ Semenkova I.G. Phytopathology. Wood destroying fungi, rot and pathological stains of wood (Definition tables). M.: MGUL, 2001.57 p.
} 
local climatic and soil conditions, resistant to diseases and pests. The root pests of the forest include the larvae of melolonthinae and other scarab beetles, click beetles and their larvae, as well as some other species that inhabit and lay eggs in the soil, where all their development takes place. Precautionary measures are to be taken against these pests, which pose a significant threat to forest nurseries, forest crops and plantations. Precautionary measures include forestry, agrotechnical and exterminating chemical (mixing of seeds before sowing with insecticides, application of insecticides into the soil and cultivation of seedlings, saplings and cuttings), aviation dusting of plantations against insects and mechanical measures of combating ${ }^{9}$.

The species composition of pests and pathogens is identified on the basis of forest pathological surveys: Pests: cockchafer (Melolontha melolontha L.); summer chafer (Amphimallon solstitiales L.); flower-eating chafer (Anomala dubia Scop.).

Branches - disease causation agents: corticoid fungi (Vuilleminia comedens Nees.); crust fungus (Impex lacteus Fr.); coral spot (Nectria cinnabarina Fr.); nummuliarian necrosis (Nummularia bulliardi Tul.).

Buds and leaves - disease causation agents: brown spotting (Gloeosporium fagi West.); mildew (Mycrosphaera alphitoides Griv.).

Pests: winter moth (Operophthera brumata L.); linder looper (Erannis defoliaria $\mathrm{Cl}$.); orange looper (Erannis aurentiaria Esp.); archips rosana (Cacoecia rosana L.);

Stems - disease causation agents: canker (Nectria galligena Bres.); tinder fungus (Fomes fomentarius (L. ex. Fr.) Gill.; willow bracket (Phellinus igniarius (L. ex. Fr.) Goel.); white stem rot (Pholiota squarosa (Mull.) Guet.); hairy curtain crust (Stereum hirsutum (Willd.) Pesc.); honey fungus (Armillariella melleae (Fr. ex. Vahl.) Karst.).

Pests: pear blight beetle (Xyleborus dispar F.); beech bark beetle (Taphrorychus bicolor Hrbst.); beech spiendour beetle (Aqrilus viridis L.); ship-timber beetle (Elateroides dermestoides L., genus of Elateroides); saperda scalaris (Saperda scalaris L., genus of Saperda); longhorn beetle (Acanthoderes clavipes Schr.); clytus antilope (Xilotrechus antipole); longhorn beetle (Leiopus nebulosus); longicorn beetle (Leptura scutellata F.); longhorn beetle (Necydalis major L.); rufous-shouldered longhorn beetle (Anaqlyptus mysticus L.); black-spotted longhorn beetle (Ragium mordax D.); death-watch beetle (Xestobium plumbeum, genus of Xestobium); fan-bearing wood-borer (Ptilinus pectinicornis L.).

The process of dying off trees at a young age often begins with the settlement in their crown of beech splendor beetle, and in the final stage leiopus nebulosus and wood-borers. The first to inhabit the trees are two-

\footnotetext{
${ }^{9}$ Semenkova I.G., Sokolova E.S. Phytopathology. M.: Academy, 2003. 468 p.
} 
colored bark, beech splendor beetle, the lower part of the trunks - a leiopus nebulosus, a leaf borer. Leiopus, as a rule, inhabit a tree when it has already been affected by fungi: a true tinder and others. An efficient measure of combating against pests and diseases is sanitary deforestation. Damaged, dry, withering, severely weakened and withered trees are selected for cutting down before mass settlement of them by stem pests or infestation. Fallen trees are subjected to immediate cutting down.

The survey found that only about $10 \%$ of the forest shelter-belts are subjected to repair and reconstruction, up to $30 \%$ are in poor condition and have to be cleared with planting new trees, $60 \%$ of the forest shelter-belts are practically absent.

In general, the overall condition of the forest shelter-belts along the route of the Kakhovka Main Canal is estimated as unsatisfactory. In the conditions of the Dry Steppe, the projected life of forest shelter-belts ( 25 years) has been already exhausted ${ }^{10}$. Trees affected by diseases and pests in a large area have died or are in extremely poor condition. With the current situation, forest shelter-belts do not perform their functions (Fig. 1).

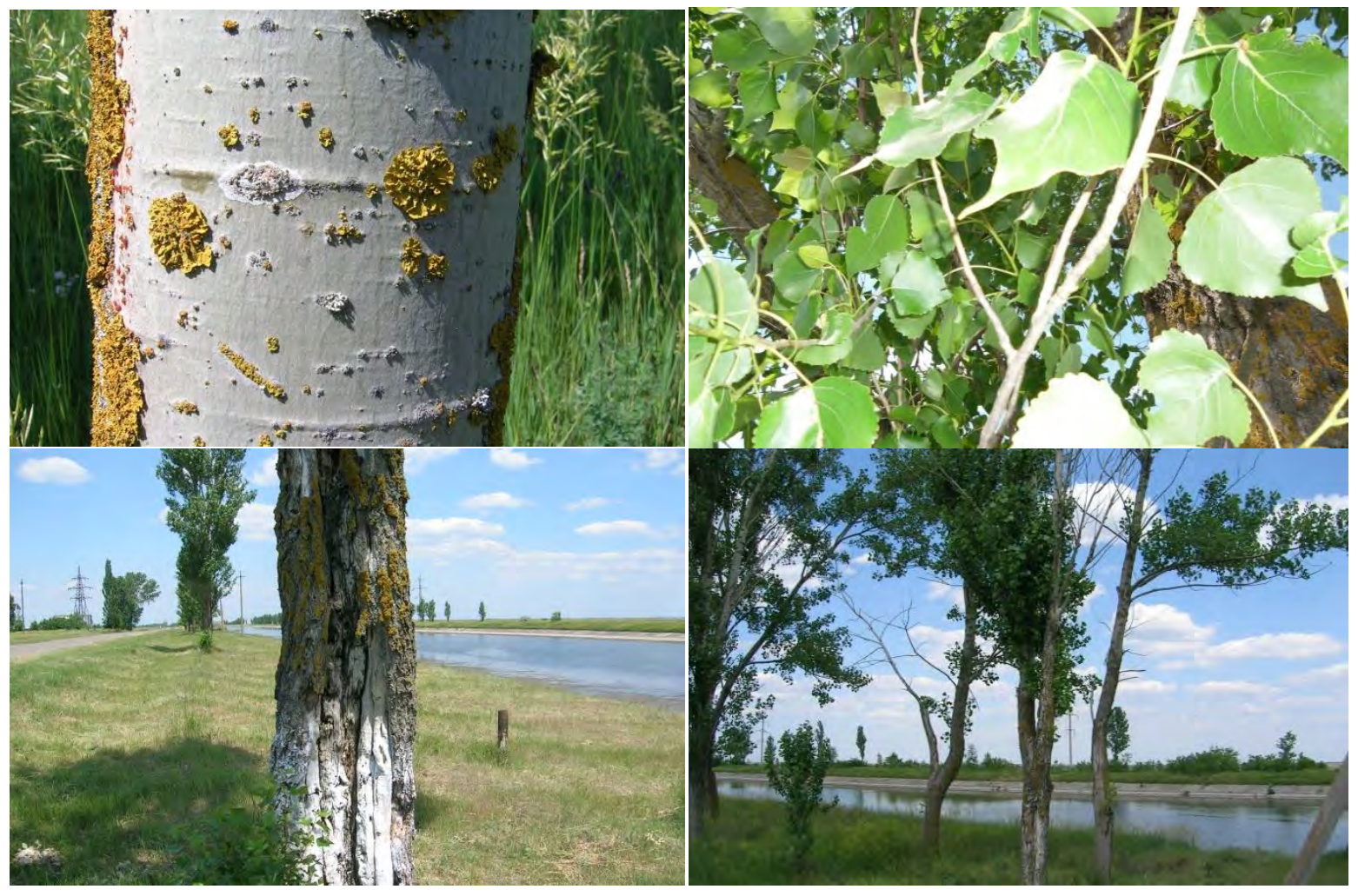

Fig. 1. Diseases and pests of forest shelter-belts

\footnotetext{
${ }^{10}$ Maksimenko N.V., Zaichenko Ya.S. Optimization of ecological-protective function of forest shelterbelts of eastern part of the Forest-steppe zone (on the example of Kharkiv region) // Coll. Article III AllUkrainian. Scient.-practic. Conf. "Environmental protection of industrial regions as a condition for sustainable development of Ukraine". Zaporizhzhya: Finway LLC, 2007. P. 164-167.
} 


\section{Scientific substantiation of necessity of their renewal and schemes of reconstruction and planting}

There is a need to scientifically justify a complex of agroforestry measures to improve the structure and composition of species of trees and shrubs of forest shelter-belts. The effectiveness and durability of forest meliorative plantations depends on the correct selection of breeds, compliance with their biological and ecological properties.

Because no breed can meet all the requirements, forest shelter-belts are created from different breeds. Thus, with plantations of honey locust and other breeds with openwork crowns it is desirable to use thick-crowned breeds. In the plantings with an oak that grows too slowly, it is required to plant trees that grow fast.

By their role, tree breeds and shrubs are divided into three groups:

- main breeds (oak, honey locust, poplar pyramidal, walnut), which form the basis of forest shelter-belts and create the upper canopy of plantations and play the main wind-breaking role. On their height depends on what distance the forest shelter-belts have effect;

- accompanying breeds (elm, ash, white acacia), which together with the main ones create an effective protection against wind in the middle part of the puncture profile of the belt, shade the soil with dense crowns, create more favorable for the main breed microclimatic conditions, promote its growth upwards and cleansing from knots;

- shrubs (Tatar maple, loch angustifolia, honeysuckle Tatar, smoketree, crataegus or hawthorn, dogrose) are used to perform protective function, regulate thermal and water regimes of soil, create close to forest conditions, which provides the best conditions for the growth of trees, creates conditions for the nesting and feeding of birds that are the natural enemies to the pests of forest plantations.

On the base of the analysis of modern scientific and practical sources and current state of the forest shelter-belts of the Kakhovka main canal, we offer the following types of forest shelter-belts along the canal - runoff-regulating afforestation. Water management forest shelter-belts are created on the slopes of arable land. They are located across the slope, preferably horizontally, which is different from the forest shelter-belts, which are perpendicular to the direction of prevailing winds.

The main assortment of recommended trees and shrubs: small-leaved elm; oak; white acacia, honey locust, Tatar maple, green ash; shrubs - dogrose, steppe blackthorn, common smoketree (local names - smoke bush), crataegus (hawthorn).

Steppe blackthorn (Prunus spinosa subsp. stepposa Kotov.), Moldavian blackthorn (Prunus spinosa subsp. moldavica Kotov) is widely spread in the Steppe of Ukraine, Prydnistrovya, western part of the Steppe and the 
Crimea. It is a branched bush (1-4 m tall) with dark gray bark and numerous spines. Young shoots are reddish-brown, short-haired or bare. Leaves are alternate elongated or elongated-oval (2-5 cm long, $1-1.8 \mathrm{~cm}$ wide), at the base the y are wedge-shaped, crenate-like, glandular. Food, honey, medicinal, tannin, dyeing, ornamental, phytomeliorative plant. In landscaping, blackthorn is used to create hedges. Blackthorn spiny or steppe is a valuable plant for creating forest shelter-belts, for securing slopes, ravines and gullies.

Smoketree or smoke bush (Cotinus coggygria Scop.; Rhus cotinus L.). A tall bush or tree of Cotinus genus (1-6 m tall) with fine-cracked brown bark. Shoots are green or purple, thick, secreting barely visible milky juice on a cut. Leaves are simple, rounded (3-8 cm long, $2-4 \mathrm{~cm}$ wide) on long (1-4 cm long) petioles, bare on the top, opaque-green, pubescent in the bottom, with a network of well-marked veins, having specific smell if rubbed. Smoketree grows in the under forest of leaf, rarely mixed forests, on dry, rocky slopes, limestone outcrops, rarely on the sands near the sea. It is a lightrequiring, frost-resistant plant. It blooms in May - June.

Smoketree is a part of the breeds in the state forest shelter-belts. It is a valuable shrub in arid regions on fertile soils; shades the soil well and reduces leaf, snow, and topsoil blowing out from forest shelter-belts. Smoketree has phytoncidal and insecticidal properties. It is established that the more smoketree in the ash plantations is, the less ash is damaged by leopard moth.

The timber is yellow or greenish-yellow with whitish sapwood, soft, light, used for small joiner-products.

Hawthorn Crataegus sanguinea Rail. Hawthorn is a tall (up to 4-8 m) shrub, rarely a small tree of the genus Rosaceae, with strong shiny shoots, usually bearing thick, straight spines $2.5-4 \mathrm{~cm}$ long, oval leaves, dark green on the top, lighter in the bottom. Inflorescences are thick, the flowers are yellowish-white, fruit are blood-red, almost transparent. It blooms in MayJune, fruiting from August to October.

It prefers sandy-pebble soils, meadow-saline, carbonate soils with close groundwater, slightly resistant to soil drought.

Hawthorn is reproduced by seeds and root shoots. Seedlings grow quite slowly. Fruiting starts in the age of 10-15 years. Life expectancy is up to 200 years and more.

Dogrose (Rosa majalis, $R$. cinnamomea), the genus of Rosaceae, (Rosa canina L). Dogrose is a shrub of Rosaceae genus, reaching a height of $1.5-3 \mathrm{~m}$, with curved, rarely almost straight branches and with green or reddish-brown bark, usually without a bluish coating. The thorns are strong, crescent-shaped, curved on the main stems, rare or scattered, sometimes almost straight, abundant on flowering branches. Leaves are 7-9 cm long, green and gray, bare, on the main stem sometimes with sparse short hairs. The flowers are usually pale pink, white or bright pink. Ripened fruit large, 15-26 mm long, 
broad-oval, rarely nearly spherical, sometimes elongated-oval, smooth, bright or light red. The inner walls of the fetus are strewn with numerous bristly hairs, among which are numerous solid, stony nuts. It blooms in May and July, fruit ripen in August - October.

The main assortment of recommended trees and shrubs:

- main breeds (oak, honey locust, poplar pyramidal, walnut);

- accompanying breeds (elm, ash, white acacia)

- shrubs (Tatar maple, silverberry, Tatar honeysuckle, blackthorn, ash, hawthorn, dogrose).

In arid conditions of the Steppe shrubs must be incorporated with trees to create shade, weed control, forest litter retention and snow accumulation 9. In order to ensure the required construction of forest shelter-belts, it is necessary to carry out sanitary cutting down, but at a young age the forest shelter-belts should not be cut down. After the first cutting of 1 ha, 1-1.5 thousand trees remain on dark chestnut soils. The repetition of cuttings is 5-10 years. In forest shelter-belts aged 10 years and more, with significant damage to the belts, empty rows are torn and kept under fallow, and then 2-3 year-old seedlings of fast-growing tree species are planted.

Forest shelter-belts with less than $25 \%$ of breeds left are decommissioned, the belts are also decommissioned provided that they have a significant proportion of trees that are dry, dominated by shrubs that do not perform protection function.

Depending on the natural and climatic conditions, the distance between rows of trees is $2 \mathrm{~m}$ in the Steppe zone on dark chestnut soils. The distance between trees is $1.0-1.5 \mathrm{~m}$. In dry Steppe conditions, forest shelter-belts should be grown under irrigation for $4-5$ years, with an irrigation rate of $500 \mathrm{~m}^{3} / \mathrm{ha}$ (5-7 waterings) in the year of planting and $600 \mathrm{~m}^{3} / \mathrm{ha}$ (4-5 waterings) in the next years ${ }^{11}$.

Under arranging forest shelter-belts, more attention should be paid to the adjacent to canal areas, especially in erosion-hazardous areas and adjacent areas of surface runoff formation. Planting of new forest shelter-belts along the canal and adjacent territories will allow to create practically new ecosystem on the basis of the Kakhovka main canal. Planting of the canal forest shelter-belts should be carried out by seedlings of the first category. Irrigation is required to ensure efficient nursery functioning. Irrigation regime of seedlings depends on soil moisture and plants conditions. Watering is performed by sprinkling or drip irrigation with irrigation rate of 100 to $400 \mathrm{~m}^{3} /$ ha depending on the irrigation method. Given the nursery's terrain and soil conditions, drip irrigation is the most effective way. Reconstruction of forest shelter-belts of the Kakhovka main canal requires a large number of

\footnotetext{
${ }^{11}$ Scientific bases of protection and rational use of the irrigated lands of Ukraine. K.: Agrarna Nauka 2009. $624 \mathrm{p}$.
} 
seedlings of trees and bushes. To grow them, you need to create a nursery for growing seedlings of trees and shrubs. Taking into account the volume of work on the reconstruction of the forest shelter-belts and their continuous maintenance, the nursery will operate on a permanent basis. Under growing material in the nursery, departments are created, first of all the breeding department with the following branches: sowing - for growing seedlings from seeds; - for growing seedlings of trees and shrubs from seedlings and cuttings; of uterine plantings - to provide the nursery with seeds and cuttings; dendrological - to create a collection of valuable species and forms of introduced and native tree breeds. Priority work in the nursery is preparation of soil and seeds for sowing. To accelerate the germination of seedlings, seeds stratification is performed. Stratified seeds are sown in well-prepared soil. When the seedlings appear, nursery workers plow the soil, destroy weeds, fertilize and water the seedlings, and protect them against diseases and pests. By sanitary condition, seedlings are divided into four categories:

- first - plants with good growth, dark-green leaves, with no signs of infestation and damage; second - growth is small, leaves are light-green (salad), there are signs of infestation or damage; third - ill, badly damaged, drying; fourth - dead ones.

Irrigation regime and irrigation method for reconstructed forest shelterbelts. The basis of the development of the regime of irrigation of forest shelter-belts is the bioclimatic method of calculating the total evaporation by the formula:

$$
E=K b \cdot \sum \mathrm{d}, \mathrm{mm}
$$

where $K_{b}$ - biological coefficient, $\mathrm{mm} / \mathrm{mbar}$

taking $\mathrm{K}_{\mathrm{b}}=0.4 \mathrm{~mm} / \mathrm{mbar}$

$\Sigma \mathrm{d}=$ the sum of daily deficits of air humidity per decade, mbar

The deficit of water balance per decade is determined by the formula:

$$
\Delta W=(E-P) \cdot \mu_{k} m m
$$

where $\mathrm{P}$ - rainfall per decade, $\mathrm{mm}$

Rainfall and humidity deficiency are accepted according to Kakhovka meteorological station.

$\mu_{\mathrm{k}}-$ microclimatic correction, it is accepted as 0.85 .

The results of determining the water balance deficit should be established for the decade of a vegetation period.

To cover the water balance deficit on the integral curve the average dates of irrigation and the magnitude of irrigation norms were determined (Table 1).

We suggest the watering of forest shelter-belts to be carried out in a surface way by blunt, flooded furrows with a depth of $25 \mathrm{~cm}$ with a slope $\mathrm{i}=<0.0005$. 
Table 1

Irrigation regime of forest shelter-belts

\begin{tabular}{|c|c|c|c|c|}
\hline \multirow{2}{*}{$\begin{array}{c}\text { No. of } \\
\text { watering }\end{array}$} & \multirow{2}{*}{$\begin{array}{c}\text { Watering } \\
\text { rate }(\mathrm{m})\end{array}$} & \multirow{2}{*}{$\begin{array}{c}\text { Average date } \\
\text { of a watering }\end{array}$} & \multicolumn{2}{|c|}{ Recommended terms } \\
\cline { 3 - 5 } & 500 & At planting & & end \\
\hline 0 & 500 & 21.05 & 16.05 & 25.05 \\
1 & 500 & 15.06 & 11.06 & 20.06 \\
2 & 600 & 07.07 & 01.07 & 10.07 \\
3 & 600 & 24.07 & 21.07 & 30.07 \\
4 & 600 & 10.08 & 16.08 & 15.08 \\
5 & 600 & 25.08 & 21.08 & 30.08 \\
6 & 500 & 10.09 & 06.09 & 15.09 \\
7 & \multicolumn{3}{|c}{} \\
\hline
\end{tabular}

Main elements of the irrigation technique

1. Water supply into a furrow $-\mathrm{q}=2.5-5 \mathrm{~L} / \mathrm{sec}$;

2. Length of a furrow $\mathrm{L}=200 \mathrm{~m}$;

3. Duration of water supply into a furrow is determined using the formula:

$$
t=\frac{1 \cdot a \cdot m}{600 \cdot \mathrm{q}} \cdot b
$$

1 - furrow length, m;

$\mathrm{a}$ - distance between the furrows, $\mathrm{m}$;

$\mathrm{m}$ - watering rate, $\mathrm{m}^{3} / \mathrm{ha}$;

$\mathrm{q}$ - water supply into the furrow, $\mathrm{L} / \mathrm{sec}$

The results of determining the duration of water supply are summarized in the Table 2 .

Table 2

Duration of water supply into a furrow, $L /$ sec

\begin{tabular}{|c|c|c|}
\hline \multirow{2}{*}{$\begin{array}{c}\text { Watering rate } \\
(\mathrm{m}) \mathrm{m}^{3} / \mathrm{ha}\end{array}$} & \multicolumn{2}{|c|}{ Water supply into a furrow, $\mathrm{L} / \mathrm{sec}$} \\
\cline { 2 - 3 } & 2.5 & 5.0 \\
\hline 500 & 67 & 33.5 \\
\hline 600 & 80 & 40 \\
\hline
\end{tabular}

Water supply from the Kakhovka main canal to the forest shelter-belts will be carried out by the means of two floating pumping stations with a rates of $10 \mathrm{~L} / \mathrm{sec}$ each and a pressure of 30 meters and 15 meters into a pressure pipe made of PVC with a diameter of $100 \mathrm{~mm}$. Watering conduction is recommended from 6:00 to 22:00. 


\section{CONCLUSIONS}

The cultivation of forest shelter-belts along the main Kakhovka canal requires considerable investment on the creation of an artificial rootcontaining horizon with a capacity of up to $1 \mathrm{~m}$. Technology of the creation of this horizon is in filling on the soil surface of a loess layer for blocking toxic renewable chemicals with further coverage of the surface with a humus layer.

Soils of existing and prospective plantings of forest shelter-belts are in a densified condition and require deep tillage to a depth of no less than $40 \mathrm{~cm}$ before planting trees; they are represented by techno-earths, which were created through covering of the surface with a humus layer with a thickness of $30-40 \mathrm{~cm}$. The structure of the canal forest shelter-belts is recommended as follows: on the edge berms of the left and right banks of the canal, there are four rows of forest shelter-belts. Forest shelter-belts consist of two rows of trees of the first breeds of forest species mixed with walnut or fruit species, along the edges there are two rows of berry bushes. Distance between the trees in the rows is from 1 to $1.5 \mathrm{~m}$, between the bushes $-0.75 \mathrm{~m}$. Intervals between the rows are $2 \mathrm{~m}$. On the inner berms of the canal, two- and threerow crafty forest shelter-belts are arranged without shrubs, depending on the size of the berms.

The main assortment of recommended trees and shrubs: main breeds (oak, honey locust, poplar pyramidal, walnut); accompanying breeds (elm, ash, white acacia); shrubs (Tatar maple, silverberry, Tatar honeysuckle, blackthorn, ash, hawthorn, dogrose). Firstly, the reconstruction of the forest shelter-belts on the berms of the canal, which are not located in the territory of the Green area, should be started. Planting of forest shelter-belts on the berms of the canal, which runs through the territory of the hearth "Green", requires the creation of an artificial root layer of soil from loess rocks up to one meter with a surface covering by a layer of humus with a thickness of 20-30 cm. To create a coherent ecosystem within the main Kakhovka canal, forest shelter-belts reconstruction should not be restricted to canal type. It is necessary to create runoff regulation and hollow-gully forest plantations on the lands adjacent to the canal. Type of crops - mixed shrubs (up to $25 \%$ of shrubs). In the areas where the forest shelter-belts cross the basin, a shrubbery must be created.

Reconstructed forest shelter-belts should be grown under the irrigated conditions for 4-5 years, with an irrigation rate of $500 \mathrm{~m}^{3} / \mathrm{ha}$ (5-7 waterings) per year of planting and $600 \mathrm{~m}^{3} /$ ha (4-5 waterings) in the next years. 105 thousand tree seedlings and 80 thousand shrubs are required to reconstruct the canal forest shelter-belts. To ensure the process of reconstruction of forest shelter-belts by planting trees and shrubs, it is necessary to create a nursery on an area of 7 hectares to grow 240-260 tree and shrubs, which has to work continuously. 
In order to ensure the necessary construction of the forest shelter-belts, it is necessary to carry out cutting down, but at a young age the forest shelter-belts should not be cut down. After the first cutting of 1 ha, 1-1.5 thousand of trees remain on dark chestnut soils. Repetition of cutting down is 5-10 years.

\section{SUMMARY}

Analysis of current state of the forest belts was conducted by the method of visual investigation. Efficiency and longevity of the forest belts along the canal depends on the right choice of trees and bushes' breeds, which have to be long-lived, grow fast and they have to be characterized with an upperintermediate feature of closing tree crowns, provide shading of soil and water surface of the canal. In general state of the forest belts along the highway of the Kakhovka main canal is unsatisfactory. The results of the investigation determined that nearly $10 \%$ of the forest belts should be repaired, $30 \%$ are in unsatisfactory condition and should be rooted out and replaced by new trees, $60 \%$ of the canal length has almost no forest belts. At the current state the forest belts do not provide protective functions. Renovated forest belts should be cultivated in the irrigated conditions during 4-5 years with the irrigation norm of $500 \mathrm{~m} 3 /$ ha (5-7 water applications) in the year of planting, and $600 \mathrm{~m}^{3} / \mathrm{ha}$ (4-5 water applications) in the next years.

\section{REFERENCES}

1. Agro-ecological monitoring and certification of agricultural lands (methodological and regulatory support) / ed. V.P. Patyka. K.: Phytosociocenter, 2002. $295 \mathrm{p}$.

2. Gladun G.B., Trofimenko M.E., Lokhmatova M.A. Forest shelter-belts: design, cultivation, arrangement / Ed. G.B. Gladunov. Kh.: Nove slovo, 2005. $390 \mathrm{p}$.

3. David O. Ekhuemelo. 2016. Importance of Forest and Trees in sustaining Water supply and Rainfall. URL: https://www.researchgate.net/publication

4. Zaichenko Y.S., Maksimenko N.V. The ecological role of forest shelterbelts in Kharkiv region. Environmental protection and rational use of natural resources. Collection of reports VII Donetsk : DonNU, 2008. P. 237-238.

5. Netherer S., Schopf A. (2010). Potential effects of climate change on insect herbivores in European forests-General aspects and the pine processionary moth as specific example. Forest Ecology and Management. 259: 831-838.

6. Gusev V.I. Determinant of damage to forest, ornamental and fruit trees and shrubs. M.: Forest. Ind., 1984. 470 p.

7. Tsylyuryk A.V., Shevchenko S.V. Forest phytopathology (Workbook). Korsun-Shevchenkovsky : Irena, 1999. 203 p. 
8. Semenkova I.G. Phytopathology. Wood destroying fungi, rot and pathological stains of wood (Definition tables). M.: MGUL, 2001. 57 p.

9. Semenkova I.G., Sokolova E.S. Phytopathology. M.: Academy, 2003. $468 \mathrm{p}$.

10. Maksimenko N.V., Zaichenko Ya.S. Optimization of ecologicalprotective function of forest shelter-belts of eastern part of the Forest-steppe zone (on the example of Kharkiv region). Coll. Article III All-Ukrainian. Scient.-practic. Conf. "Environmental protection of industrial regions as a condition for sustainable development of Ukraine". Zaporizhzhya : Finway LLC, 2007. P. 164-167.

11. Scientific bases of protection and rational use of the irrigated lands of Ukraine. K.: Agrarna Nauka, 2009. 624 p.

Information about authors: Vozhehova R. A.,

Doctor of Agricultural Science, Professor, Corresponding Member the National Academy of Agrarian Sciences of Ukraine, Director Institute Irrigated Agriculture of the National Academy Agrarian Sciences of Ukraine Naddnipryanske sett., Kherson, 73483, Ukraine

Hranovska L. M.,

Doctor of Economics Sciences, Professor, Head of the Department of Irrigated Agriculture Institute Irrigated Agriculture of the National Academy Agrarian Sciences of Ukraine Naddnipryanske sett., Kherson, 73483, Ukraine 